\title{
Fatty acid profile and nutritional composition of table eggs after supplementation by pumpkin and flaxseed oils
}

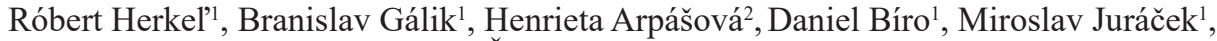 \\ Milan Šimko ${ }^{1}$, Michal Rolinec ${ }^{1}$
}

Slovak University of Agriculture in Nitra, Faculty of Agrobiology and Food Resources, ${ }^{1}$ Department of Animal Nutrition, ${ }^{2}$ Department of Poultry Science and Small Animal Husbandry, Nitra, Slovakia

Received January 29, 2016

Accepted August 31, 2016

\begin{abstract}
The aim of this study was to determine the effect of pumpkin and flaxseed oils on the fatty acid profile and nutrient changes in table eggs. At 38 weeks of age, Lohmann Brown Lite hens were divided into three groups depending up the diet. The birds were housed in individual cages (6 hens per cage) with a space allowance of $943.2 \mathrm{~cm}^{2}$ per hen, and given diet standard complete feed mixture for laying hens. Hens from experimental groups were fed with complete feed mixtures supplemented by pumpkin (group E1) or flaxseed (group E2) oils at a dosage of $3 \%$. The experiment lasted 52 days. In the last week of the trial, the eggs were collected for chemical analysis. Twelve eggs from each dietary treatment were randomly selected and analysed. Significant differences between control and group E1 in the content of crude protein $(P<0.05)$, between both experimental groups (E1 and E2) in the content of ash $(P<0.01)$ in yolk, and between control and the experimental groups in the content of dry matter $(P<0.05)$ in albumen were detected. Significant $(P<0.01)$ differences were found in contents of myristic, palmitic, heptadecanoic, oleic, linoleic, and cis-11,14-eicosadienoic acids between control and experimental groups E1 and E2. Compared to control, higher $(P<0.01)$ concentrations of monounsaturated fatty acids, lower concentrations of saturated fatty acids and also lower contents of polyunsaturated fatty acids in the experimental groups were observed. The supplementation of flaxseed oil had a positive effect on the content of $n-3 \alpha$-linolenic acid.
\end{abstract}

Albumen, laying hens, nutrients, plant fats, yolk

Dietary fat type and fatty acid (FA) composition of consumed fats are more important than the amount of dietary consumed cholesterol (Simopoulos 2000). Lipids contribute to approximately $65 \%$ of the dry matter content of egg yolk (Anton 2007). It has been reported that the pure components of essential oils inhibit hepatic 3-hydroxy-3methylglutaryl coenzyme A (HMGCoA) reductase activity which is a key regulatory enzyme in cholesterol synthesis (Crowell 1999). Animal organism cannot create essential fatty acids and for its correct functioning, these acids must be received in the diet (Chow 2008). The results of many studies have confirmed that saturated fatty acids and trans fatty acids have negative effects on human health, whereas polyunsaturated fatty acids have a positive effect on human health as regards the coronary heart disease (Erkkila et al. 2003). Pumpkin seeds contain L-tryptophan, n-6 and n-3 fatty acids and a very high concentration of vitamin E (Hashemi 2013). Pumpkin seed oil has become a recognized source of phenolic compounds (Andjelkovic et al. 2010). Flaxseed oil contains high levels of polyunsaturated fatty acids and these compounds have been reported to reduce the incidence of heart disease and cancer in humans (Zhao et al. 2007). Changes in lipid metabolism in various animals were achieved by the addition of various additives to the diet (Capcarova et al. 2011; Emrichová et al. 2013; Petruška et al. 2013; Zbyňovská et al. 2014). The aim of this study was to determine the effect of pumpkin and flaxseed oils on the fatty acid profile and nutrient changes in table eggs.

Address for correspondence:

Branislav Gálik

Slovak University of Agriculture in Nitra

Tr. A. Hlinku 2, 949 76, Nitra, Slovakia
Phone: +421376414331

E-mail: Branislav.Galik@uniag.sk

http://actavet.vfu.cz/ 
Animals and housing

\section{Materials and Methods}

At 38 weeks of age, Lohmann Brown Lite hens were housed in three-floor cages (six hens in one cage; with a space allowance of $943.2 \mathrm{~cm}^{2}$ per hen), divided into three dietary of groups (C - control, E1 - pumpkin oil, E2 - flaxseed oil). A total of 18 hens were monitored. During the experiment, the light regime was set at $16 \mathrm{~h}$. The experiment lasted 52 days. The laying hens were kept in standard bioclimatic and welfare conditions. In this animal study, institutional and national guidelines for the care and use of animals were followed, and all experimental procedures involving animals were approved by the ethics committee. All efforts were made to minimize the animals' suffering.

\section{Feeding}

In the control group hens were fed a standard complete feed mixture for laying hens; in the experimental groups hens were fed feed mixtures supplemented by pumpkin (E1) or flaxseed (E2) oils at a concentration of $3 \%$. Pure by the origin and virgin oils (mechanically pressed by cold technology) were used in the experiment. Vitamin E $(0.1 \mathrm{~g}$ per $1 \mathrm{~kg}$ of feed) was added into feed mixture in the experimental groups. Laying hens in all groups received drinking water and feed mixture ad libitum. Feeding mixture was composed of wheat, corn, soybean meal, rapeseed meal, sunflower meal, animal fat, soybean oil, calcium carbonate, feed additives, sodium bicarbonate, monocalcium phosphate, sodium chloride and enzyme complex of phytase. The fatty acid profile of oils is shown in Table 1 and the nutrient composition of feed mixtures after addition of oils is presented in Table 2 .

Table 1. Fatty acid profile of oils.

\begin{tabular}{|c|c|c|}
\hline Fatty acid & $\begin{array}{l}\text { Flaxseed oil } \\
\% \text { of crude fat }\end{array}$ & Pumpkin oil \\
\hline Myristic & 0 & 0.11 \\
\hline Palmitic & 5.59 & 11.13 \\
\hline Palmitoleic & 0.08 & 0.12 \\
\hline Heptadecanoic & 0.03 & 0 \\
\hline Stearic & 4.61 & 6.19 \\
\hline Oleic & 18.95 & 38.87 \\
\hline Linoleic & 31.38 & 41.37 \\
\hline$\alpha$-linolenic & 37.63 & 0.17 \\
\hline Arachidic & 0.15 & 0.45 \\
\hline Cis-11-eicosenoic & 0.13 & 0.12 \\
\hline Behenic & 0.14 & 0.14 \\
\hline Lignoceric & 0.23 & 0.09 \\
\hline Ratio $\Sigma \mathrm{n} 3 / \Sigma \mathrm{n} 6$ & 1.2 & 0 \\
\hline Ratio $\Sigma \mathrm{n} 6 / \Sigma \mathrm{n} 3$ & 0.83 & 248.04 \\
\hline
\end{tabular}

Sampling and laboratory analysis

During the last week of the trial the eggs were collected for chemical analysis. Twelve eggs from each dietary group were randomly selected and analysed. Nutrient composition of diets and eggs were determined by standard laboratory methods and procedures (AOAC 2000) in the Laboratory of Quality and Nutritive Value of Feeds (Department of Animal Nutrition, Faculty of Agrobiology and Food Resources, Slovak University of Agriculture in Nitra, Slovak Republic). The content of crude fat was determined by extraction and gravimetric method according to the Soxhlet principle. The sample in the analytic tube was dried for

Table 2. Nutrient composition of feed mixtures for experimental groups.

\begin{tabular}{lccrr}
\hline Nutritive & Unit & C & E1 & E2 \\
\hline Dry matter & \% & 91.12 & 90.88 & 91.4 \\
Crude protein & \% of DM & 17.68 & 17.81 & 17.45 \\
Fat & \% of DM & 6.53 & 7.61 & 7.59 \\
Fiber & \% of DM & 4.09 & 3.71 & 3.78 \\
Ash & \% of DM & 12.01 & 11.49 & 11.26 \\
NFE & \% of DM & 50.81 & 50.26 & 51.32 \\
Organic matter & \% of DM & 79.11 & 79.39 & 80.14 \\
Starch & \% of DM & 35.3 & 35.62 & 35.45 \\
Sugar & \% of DM & 3.9 & 3.84 & 3.94 \\
\hline
\end{tabular}

NFE - nitrogen free extract, DM - dry matter 
$30 \mathrm{~min}$ at $100{ }^{\circ} \mathrm{C}$. After drying, cooling and weighing, petroleum extract was added and the sample was extracted for $60 \mathrm{~min}$ at $40-65^{\circ} \mathrm{C}$ on the apparatus Soxtec System HT 1043 Extraction Unit (Tecator, Sweden). For the characteristics of lipid fraction, triglycerides were hydrolyzed to glycerol and free fatty acids. Fatty acids were then derivative to methylesters. After their preparation, acids were separated on the basis of carbon number and level of unsaturation by gas chromatography fitted with a flame-ionization detector (FID). For the identification column 37 components mixture (Supleco 47885-U) was used. Standard solution was diluted with $10 \mathrm{ml}$ of hexane, $1 \mathrm{ml}$ supplementation of $2 \mathrm{~N}$ potassium hydroxide in methanol. The analytic tube was heated for $30 \mathrm{~s}$ at $60{ }^{\circ} \mathrm{C}$ in a water bath. After $1 \mathrm{~min}, 2 \mathrm{ml}$ of $1 \mathrm{~N}$ hydrochloric acid were added. The top layer was transferred at the amount of $2 \mathrm{ml}$ to an autosampler vial with ninhydrin. Injection of samples was performed by injection autosampler Agilent. The content of fatty acids as a percentage in crude fat was determined on the machine Agilent 6890A GC (Agilent Technologies, USA).

\section{Statistical analysis}

The data used for statistical evaluation of nutrients represent means of values obtained from 12 eggs from each group. Differences between groups were analyzed with one-way analysis of variance (ANOVA) by using the statistical programme IBM SPSS 20.0. Results were evaluated using Tukey test. Values with different superscripts within a column or row are significant ( ${ }^{\mathrm{ab}}$ at $P<0.05,{ }^{\mathrm{AB}}$ at $\left.P<0.01\right)$. Relationships between nutrients were assessed on the base Pearson correlation coefficient.

\section{Results}

Table 3. The nutritional composition of egg yolk.

\begin{tabular}{|c|c|c|c|c|c|}
\hline Group & Statistical indicator & $\begin{array}{c}\mathrm{DM} \\
\mathrm{g} \cdot \mathrm{kg}^{-1}\end{array}$ & $\begin{array}{c}\mathrm{CP} \\
\mathrm{g} \cdot \mathrm{kg}^{-1} \text { of } \mathrm{DM}\end{array}$ & Fat & Ash \\
\hline \multirow{3}{*}{$\mathrm{C}$} & Mean & 478.58 & $311.98^{\mathrm{a}}$ & 595.35 & $33.73^{\mathrm{AB}}$ \\
\hline & SD & 8.75 & 5.3 & 7.65 & 1.11 \\
\hline & $\mathrm{CV}$ & 76.62 & 28.11 & 58.52 & 1.23 \\
\hline \multirow{3}{*}{ E1 } & Mean & 489.23 & $318.57^{\mathrm{b}}$ & 598.25 & $34.98^{\mathrm{B}}$ \\
\hline & SD & 10.25 & 2.08 & 5.22 & 0.97 \\
\hline & $\mathrm{CV}$ & 104.99 & 4.34 & 27.21 & 0.93 \\
\hline \multirow{3}{*}{ E2 } & Mean & 491.47 & $316.17^{\mathrm{ab}}$ & 600.63 & $33.08^{\mathrm{A}}$ \\
\hline & SD & 7.14 & 2.56 & 5.92 & 0.49 \\
\hline & $\mathrm{CV}$ & 50.99 & 6.56 & 35.06 & 0.24 \\
\hline
\end{tabular}

DM - dry matter, CP - crude protein, SD - standard deviation, CV - coefficient of variance.

Values with different superscripts within a column are significant $\left({ }^{\mathrm{ab}} P<0.05,{ }^{\mathrm{AB}} P<0.01\right)$

Table 4. The nutritional composition of egg albumen.

\begin{tabular}{lcccc}
\hline Group & Statistical indicator & $\begin{array}{c}\mathrm{DM} \\
\mathrm{g} \cdot \mathrm{kg}^{-1}\end{array}$ & $\begin{array}{c}\mathrm{CP} \\
\mathrm{g} \cdot \mathrm{kg}^{-1} \text { of DM }\end{array}$ & Ash \\
\hline C & Mean & $116.53^{\mathrm{a}}$ & 816.98 & 66.08 \\
& $\mathrm{SD}$ & 7.77 & 24.6 & 2.66 \\
& $\mathrm{CV}$ & 60.4 & 605.234 & 7.07 \\
E1 & Mean & $125.8^{\mathrm{b}}$ & 812.03 & 63.87 \\
& $\mathrm{SD}$ & 1.29 & 18.14 & 1.96 \\
& $\mathrm{CV}$ & 1.68 & 329.04 & 3.85 \\
E2 & Mean & $124.2^{\mathrm{b}}$ & 808.18 & 63.38 \\
& $\mathrm{SD}$ & 2.6 & 20.32 & 2.99 \\
& $\mathrm{CV}$ & 6.76 & 413.01 & 8.93 \\
\hline
\end{tabular}

DM - dry matter, CP - crude protein, SD - standard deviation, CV - coefficient of variance.

Values with different superscripts within a column are significant at $P<0.05$. 
The nutritional composition of egg yolk and albumen are shown in Tables 3 and 4 . Significant differences between control and group E1 in the content of crude protein $(P<0.05)$ and between both experimental groups (E1 and E2) in the content of ash $(P<0.01)$ in yolk were found. Tendency $(P>0.05)$ for a higher content of dry matter and fat was detected after both oil supplementations in yolk compared to control. The highest contents of dry matter and fat in group E2 (flaxseed oil supplementation), crude protein and ash in group E1 (pumpkin oil supplementation) in yolk were measured. The dry matter content was significantly $(P<0.05)$ higher in albumen in both experimental groups compared to the control group. The crude protein and ash in albumen were lower $(P>0.05)$ after addition of oils compared to the control. Some relations between fat and other nutrients in yolk were detected. Positive significant $(P<0.01)$ correlation was found between the content of fat and dry matter $(r=0.772)$.

Table 5. The fatty acid profile in egg yolk (as \% mean $\pm \mathrm{SD})$.

\begin{tabular}{lccc}
\hline Fatty acid & \multicolumn{1}{c}{ Group } & E2 \\
\hline Myristic & $0.29^{\mathrm{B}} \pm 0.007$ & $0.27^{\mathrm{A}} \pm 0.004$ & $0.27^{\mathrm{A}} \pm 0.004$ \\
Palmitic & $22.46^{\mathrm{B}} \pm 0.19$ & $21.09^{\mathrm{A}} \pm 0.46$ & $20.80^{\mathrm{A}} \pm 0.25$ \\
Palmitoleic & $2.68 \pm 0.31$ & $2.69 \pm 0.29$ & $2.84 \pm 0.15$ \\
Heptadecanoic & $0.23^{\mathrm{B}} \pm 0.02$ & $0.18^{\mathrm{A}} \pm 0.01$ & $0.18^{\mathrm{A}} \pm 0.002$ \\
Stearic & $6.17^{\mathrm{AB}} \pm 0.18$ & $5.93^{\mathrm{A}} \pm 0.04$ & $6.48^{\mathrm{B}} \pm 0.34$ \\
Oleic & $40.53^{\mathrm{A}} \pm 1.17$ & $45.71^{\mathrm{B}} \pm 0.79$ & $44.81^{\mathrm{B}} \pm 0.53$ \\
Linoleic & $20.60^{\mathrm{B}} \pm 1.66$ & $17.04^{\mathrm{A}} \pm 0.98$ & $15.13^{\mathrm{A}} \pm 0.65$ \\
$\alpha$-linolenic & $0.70^{\mathrm{A}} \pm 0.09$ & $0.70^{\mathrm{A}} \pm 0.46$ & $3.59^{\mathrm{B}} \pm 0.22$ \\
$\gamma$-linolenic & $0.05 \pm 0.06$ & $\mathrm{ND}$ & $\mathrm{ND}$ \\
Arachidonic & $1.40^{\mathrm{B}} \pm 0.06$ & $1.26^{\mathrm{B}} \pm 0.11$ & $0.85^{\mathrm{A}} \pm 0.02$ \\
Cis-11-eicosenoic & $0.27^{\mathrm{B}} \pm 0.008$ & $0.27^{\mathrm{B}} \pm 0.01$ & $0.20^{\mathrm{A}} \pm 0.006$ \\
Cis-11,14-eicosadienoic & $0.27^{\mathrm{C}} \pm 0.01$ & $0.22^{\mathrm{B}} \pm 0.02$ & $0.14^{\mathrm{A}} \pm 0.005$ \\
Cis-8,11,14-eicosatrienoic & $0.11 \pm 0.05$ & $0.11 \pm 0.009$ & $0.09 \pm 0.04$ \\
Nervonic & $0.50^{\mathrm{A}} \pm 0.03$ & $0.37^{\mathrm{A}} \pm 0.06$ & $0.89^{\mathrm{B}} \pm 0.09$ \\
Ratio $\Sigma \mathrm{n} 3 / \Sigma \mathrm{n} 6$ & 0.03 & 0.04 & 0.22 \\
Ratio $\Sigma \mathrm{n} 6 / \Sigma \mathrm{n} 3$ & 32.40 & 35.71 & 4.52 \\
\hline SD & & &
\end{tabular}

SD - standard deviation, ND - not detected.

Values with different superscripts within a row are significant at $P<0.01$.

The fatty acid profile of egg yolk is summarized in Table 5. The contents of myristic, palmitic, heptadecanoic, linoleic, and cis-11,14-eicosadienoic acids were significantly $(P<0.01)$ lower in both experimental groups compared to the control group. No significant $(P>0.05)$ differences were found in the content of palmitoleic and cis8,11,14-eicosatrienoic acid between groups; however, palmitoleic acid was higher in the yolks of hens fed both oil-supplemented diets. The stearic acid content was higher $(P>0.05)$ only in the experimental group E2 (flaxseed oil supplementation) compared to the control group. Oleic acid comprised the highest percentage of fatty acids in yolk samples of all groups. Its content was significantly $(P<0.01)$ higher in yolks after the addition of oils compared to the control. Alpha-linoleic acid, n-3 essential fatty acid, was markedly higher after flaxseed oil supplementation compared to the control group. Occurrence of $\gamma$-linolenic acid was detected only in yolk of the control group. The content of arachidonic acid, n-6 essential fatty acid, was significantly 
$(P<0.01)$ the lowest in the E2 group. Significant $(P<0.01)$ differences between the control and group E2 (flaxseed oil supplementation) in the content of cis-11eicosenoic acid were detected. The highest $(P<0.01)$ content of nervonic fatty acid was observed after flaxseed oil supplementation. Significantly $(P<0.05)$ negative Pearson correlation coefficient was found between the content of fat and linoleic acid $(\mathrm{r}=-0.489)$. The optimal $\mathrm{n}-6 / \mathrm{n}-3$ ratio was detected in group E2 (4.52).

The contents of polyunsaturated fatty acids (PUFA), monounsaturated fatty acids (MUFA) and saturated fatty acids (SFA) are shown in Fig. 1. Significant $(P<0.01)$ differences were found for all acids between control and the two experimental groups. The PUFA especially include linoleic, arachidonic and $\alpha$-linolenic fatty acids. Oleic acid is the most important fatty acid of MUFA. The SFA mainly constitute palmitic and stearic fatty acids.

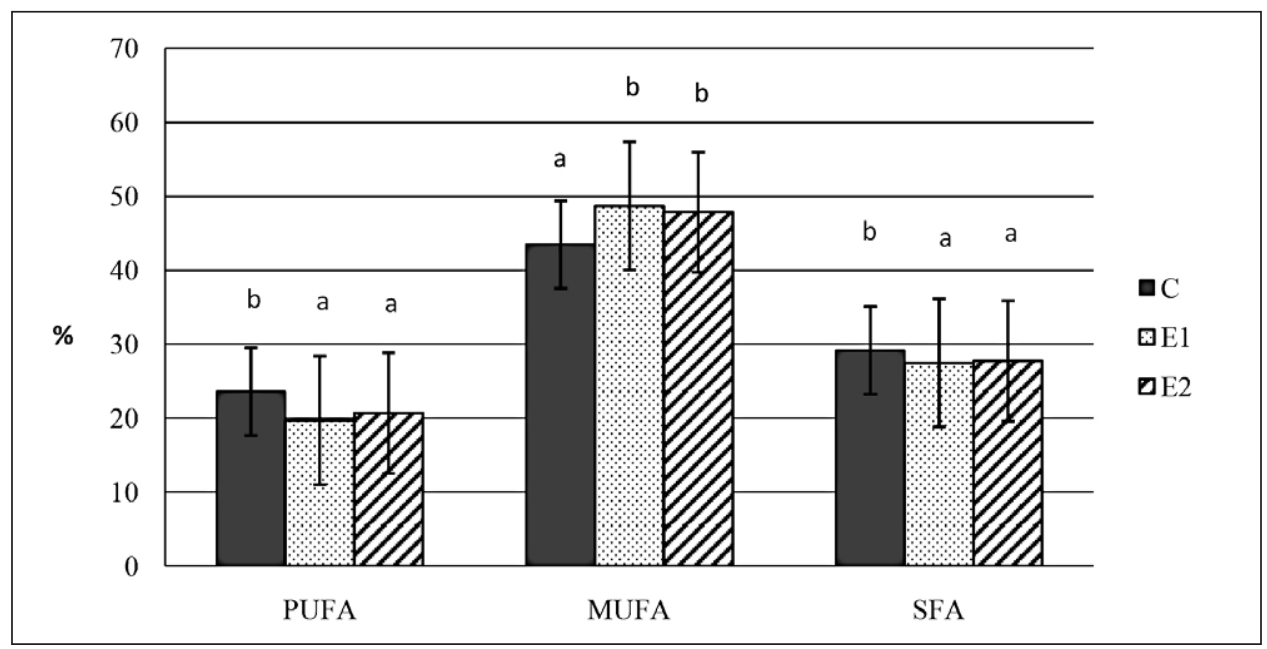

Fig. 1. Comparison of unsaturated and saturated fatty acids among the groups $(n=6)$

PUFA: polyunsaturated fatty acids, MUFA: monounsaturated fatty acids, SFA: saturated fatty acids. Differences were significant at $P<0.01$.

\section{Discussion}

The effect of plant oils on nutrient composition of table eggs was studied by Ansari et al. (2006), Quirino et al. (2009), Martínez et al. (2012) and other authors. Ruzsíková et al. (2010) found results similar to ours for the contents of dry matter, crude protein, fat and ash in egg yolk. Antruejo et al. (2011) detected 35.75\% fat content in yolk (flaxseed), 36.71\% in yolk (flax oil) and $37.15 \%$ in yolk (chia oil) of eggs after addition of different fat sources into the feed mixture. Quirino et al. (2009) recorded 33.23\% lipid content in yolk after the addition of soybean oil. Hayat et al. (2009) found that the total lipid content was higher after flaxseed addition compared to the control group, as we did in our trial. In a study by Ansari et al. (2006), flaxseed supplementation (0, 5, 10 and $15 \%$ of the diet) did not affect the total fat content of the yolks at any level. Contents of protein were found to be $15.74 \%$ in albumen and $10.20 \%$ in yolk in a group with soybean oil addition in diet (Quirino et al. 2009). Quirino et al. (2009) also found lower contents of ash (0.5\% in yolk, $1.65 \%$ in albumen) after soybean oil supplementation compared to our results. 
After pumpkin and flaxseed oil supplementation, we found a lower content of myristic acid in eggs. However, a higher content of myristic acid after linseed supplementation in diet was reported by Hudečková et al. (2012). In our study, the content of palmitic acid was lower in groups with oil additions in diets compared to control. Similarly, Basmacıoğlu et al. (2003) reported a lower content of palmitic acid after flaxseed and fish oil supplementations. Hudečková et al. (2012) found a tendency for higher palmitic acid concentration in table eggs after lineseed supplementation in the diet of laying hens. Antruejo et al. (2011) found a significantly $(P<0.05)$ higher content of palmitic acid in the yolks of hens fed non-enriched $\alpha$-linoleic diets. In contrast, Martínez et al. (2012) found a higher content of palmitic acid after pumpkin oil supplementation. We recorded higher concentrations of palmitoleic acid in both experimental groups similarly as B asmac1oğlu et al. (2003) at $4.32 \%$ flaxseed content in the treatment. In our study, a lower content of stearic acid was recorded in group E1 compared to the control group, and a higher content of stearic acid in group E2. Higher contents of stearic acid after oil addition were recorded in the studies of B as maciog $\mathrm{lu}$ et al. (2003) and Martínez et al. (2012). In our trial as well as in experiments of other authors (Basmac1oğlu et al. 2003; Martínez et al. 2012), an increase in the content of oleic acid after oil supplementations was detected. Oleic acid is the most widespread in natural lipids, with palmitoleic acid being the second. Oleic acid-rich vegetable oils seem to lower the less desirable forms of blood cholesterol, low-density lipoprotein (LDL) with high fat intake, and to increase more desirable forms of cholesterol, highdensity lipoprotein (HDL) (Ronzio 2003; Chow 2008). In our study, the content of linoleic and arachidonic acids (n-6 fatty acids) was lower in both experimental groups compared to control. Similar results were recorded by Basmacioğlu et al. (2003), Antruejo et al. (2011). The amount of $\alpha$-linolenic acid (n-3 fatty acid) increased after the addition of flaxseed oil to the diets in our experiment. These results were similar to those reported by Gonzalez-Esquerra and Leeson (2000), Meluzzi et al. (2000), Basmacıoğlu et al. (2003) and Rowghani et al. (2007). Essential polyunsaturated fatty acids are divided into n-3 and n-6 fatty acids. They are essential for healthy growth and development and play an important role in the prevention and treatment of coronary heart disease, hypertension, inflammation, autoimmune disorders and cancer. They exhibit anti-inflammatory, anti-thrombotic, vasodilatory, anti-atherogenic properties and can modulate lipid metabolism in a beneficial way (Lewis et al. 2000; Connor 2007). The total of saturated fatty acids in our study decreased in both experimental groups. Similar results were published by Basmacıoğlu et al. (2003). Due to the increase in n-3 fatty acids and decrease in n-6 fatty acids in eggs of our experimental animals, the ratio of $\mathrm{n} 6 / \mathrm{n} 3$ fatty acids was reduced from 32.4 to 4.52 after flaxseed oil supplementation. Basmacıoğlu et al. (2003) also reported decreasing of ratio of n6/n3 fatty acids after flaxseed addition. The important ratios of n6/n3 and saturated fatty acids/poly-unsaturated fatty acids were lower $(P<0.05)$ with $3.3,6.6$, and $10 \%$ of pumpkin seed meal, compared to control (Martínez et al. 2012). Simopoulos (2002) recommended a ratio of 2.1/1. Oil supplementations of feed mixtures positively influenced the contents of all basic nutrients in yolk except for ash after the addition of flaxseed oil. Only the dry matter content was higher in albumen in the experimental groups compared to control. The addition of flaxseed oil had a positive effect on the content of important $n 3$ fatty acid $\alpha$-linolenic acid. However, lower contents of linoleic and arachidonic fatty acids were detected in both experimental groups.

\section{Acknowledgement}

This study was supported by Scientific Grant Agency of the Ministry of Education, Science, Research and Sport of the Slovak republic and Slovak Academy of Sciences (project No. 1/0723/15). 


\section{References}

Andjelkovic M, Van Camp J, Trawka A, Verhé R 2010: Phenolic compounds and some quality parameters of pumpkin seed oil. Eur J Lipid Sci Tech 112: 208-217

Ansari R, Azarbayejani A, Ansari S, Asgari S, Gheisari A 2006: Production of egg enriched with omega-3 fatty acids in laying hens. ARYA Atheroscler 1: 242-246

Anton M 2007: Composition and structure of hen egg yolk. Bioactive egg compounds, Springer-Verlag. Berlin Heidelberg, pp 1-7

Antruejo A, Azcona JO, Garcia PT, Gallinger C, Rosmini M, Ayerza R, Coates W, Perez CD 2011: Omega-3 enriched egg production: the effect of $\alpha$-linolenic $\omega-3$ fatty acid sources on laying hen performance and yolk lipid content and fatty acid composition. Br Poult Sci 52: 750-760

AOAC 2000: Official methods of analysis. Association of official analytical chemists, Washington

Basmacioglu H, Cabuk M, Unal K, Ozkan K, Akkan S, Yalcin H 2003: Effects of dietary fish oil and flax seed on cholesterol and fatty acid composition of egg yolk and blood parameters of laying hens. S Afr J Anim Sci 33: 266

Capcarova M, Slamecka J, Abbas K, Kolesarova A, Kalafova A, Valent M, Filipejova T, Chrastinova L, Ondruska L, Massanyi P 2011: Effects of dietary inclusion of Rhus coriaria on internal milieuof rabbits. J Animal Physiol Anim Nutr 96: 459-465

Connor WE 2007: Importance of $\omega-3$ fatty acids in health and disease. Am J Clin Nutr 71: 171-175

Crowell PL 1999: Prevention and therapy of cancer by dietary monoterpenes. J Nutr 129: 775-778

Emrichová J, Kalafová A, Zbyňovská K, Petruška P, Ondruška L, Jurčík R, Chrastinová L, Kováčik A, Schneidgenová M, Čupka P, Capcarová M. 2013: Effect of oral administration of strawberry leaves on haematological parameters of male rabbits: four week exposure. In: NutriNET 2013. Slovak University of Agriculture, Nitra, pp 25-29

Erkkila AT, Lehto S, Pyorala K, Uusitupa MI 2003: n-3 fatty acids and 5-y risks of death and cardiovascular disease events in patients with coronary artery disease. Am J Clin Nutr 78: 65-71

Gonzalez-Esquerra R, Leeson S 2000: Effect of feeding hens regular or deodorized menhaden oil on production parameters, yolk fatty acid profile, and sensory quality of eggs. Poult Sci 79: 1597-1602

Hashemi JM 2013: Pumpkin seed oil and vitamin E improve reproductive function of male rats inflicted by testicular injury. World Appl Sci J 23: 1351-1359

Hayat Z, Cherian G, Pasha TN, Khattak FM, Jabbar MA 2009: Effect of feeding flax and two types of antioxidants on egg production, egg quality, and lipid composition of eggs. J Appl Poultry Res 18: 541-551

Hudečková P, Rusníková L, Straková E, Suchý P, Marada P, Macháček M 2012: The effect of lineseed oil supplementation of the diet on the content of fatty acids in the egg yolk. Acta Vet Brno 81: 159-162

Chow CK 2008: Fatty acids in foods and their health implications. CRC Press, Boca Raton, 1298 p.

Lewis NM, Seburg S, FLanagan N L 2000: Enriched eggs as a source of N-3 polyunsaturated fatty acids for humans. Poult Sci 79: 971-974

Martínez Y, Valdivié M, Solano G, Estarrón M, Martínez O, Córdova J 2012: Effect of pumpkin (Cucurbita maxima) seed meal on total cholesterol and fatty acids of laying hen eggs. Cuban J Agr Sci 46: 73-78

Petruška P, Kalafová A, Kolesárová A, Zbyňovská K, Latacz A, Capcarová M 2013: Effect of quercetin on haematological parameters of rabbits: a gender comparison. J Microb Biotech Food Sci 2: 1540-1549

Meluzzi A, Sirri F, Manfreda G, Talarico N, Franchini A 2000: Effects of dietary vitamin E on the quality of table eggs enriched with n-3 long-chain fatty acids. Poult Sci 79: 539-545

Quirino BJDS, Costa FGP, Queiroga RDCRD, Pereira WE, Neto L, da Cunha R, Souza JGD 2009: Effect of different metabolizable energy and soybean oil levels in the diet of laying hens on the egg chemical composition and lipid profile. Rev Bras Zootec 38: 685-689

Ronzio R 2003: The Encyclopedia of Nutrition and Good Health. Fact on File, New York, 726 p.

Rowghani E, Arab M, Nazifi S, Bakhtiari Z 2007: Effect of canola oil on cholesterol and fatty acid composition of egg-yolk of laying hens. Inter J Poult Sci 2: 111

Ruzsíková E, Horniaková E, Gálik B 2010: Enzymes in laying hens nutrition and their influence on the performance, energy and mineral composition of eggs of layers fed diet with higher content of non-starch polysaccharides. Mendel Net 325-332

Simopoulos AP 2000: Human requirement for N-3 polyunsaturated fatty acids. Poult Sci 79: 961-970

Simopoulos AP 2002: The importance of the ratio of omega- 6/omega-3 essential fatty acids. Biomed Pharmacother 56: 365

Zbyňovská K, Kalafová A, Petruška P, Emrichová J, Ondruška L, Jurčík R, Chrastinová L', Capcarová M 2014 : Evaluation of some biochemical parameters in rabbits blood after two weeks exposure of epicatechin. J Microb Biotech Food Sci 3: 184-186

Zhao G, Etherton TD, Martin KR, Gillies PJ, West SG, Kris-Etherton PM 2007: Dietary $\boldsymbol{\alpha}$-linolenic acid inhibits proinflammatory cytokine production by peripheral blood mononuclear cells in hypercholesterolemic subjects. Am J Clin Nutr 85: 385-391 